\title{
IODP Expedition 335: Deep Sampling in ODP Hole 1256D
}

\author{
by Damon A.H. Teagle, Benoit Ildefonse, Peter Blum and \\ the IODP Expedition 335 Scientists
}

\begin{abstract}
Observations of the gabbroic layers of untectonized ocean crust are essential to test theoretical models of the accretion of new crust at mid-ocean ridges. Integrated Ocean Drilling Program (IODP) Expedition 335 ("Superfast Spreading Rate Crust 4”) returned to Ocean Drilling Program (ODP) Hole $1256 \mathrm{D}$ with the intention of deepening this reference penetration of intact ocean crust a significant distance $(\sim 350 \mathrm{~m})$ into cumulate gabbros. Three earlier cruises to Hole 1256D (ODP 206, IODP 309/312) have drilled through the sediments, lavas, and dikes and $100 \mathrm{~m}$ into a complex dike-gabbro transition zone.
\end{abstract}

erations during this and previous expeditions. At the end of Expedition 335, we briefly resumed coring before undertaking cementing operations to secure problematic intervals. To ensure the greatest scientific return from the huge efforts to stabilize this primary ocean lithosphere reference site, it would be prudent to resume the deepening of Hole 1256D in the nearest possible future while it is open to full depth.

\section{Why Study Ocean Crust Forming at Fast Spreading Rates?}

The vast majority ( 70\%) of magma derived from the mantle is brought into the Earth's crust at the mid-ocean ridges, and approximately two-thirds of that magma cools
Operations on IODP Expedition 335 proved challenging throughout, with almost three weeks spent re-opening and securing unstable sections of the hole. When coring commenced, the comprehensive destruction of the coring bit required further remedial operations to remove junk and huge volumes of accumulated drill cuttings. Hole-cleaning operations using junk baskets were successful, and they recovered large irregular samples that document a hitherto unseen sequence of evolving geological conditions and the intimate coupling between temporally and spatially intercalated intrusive, hydrothermal, contact-metamorphic, partial melting, and retrogressive processes.

Hole $1256 \mathrm{D}$ is now clean of junk, and it has been thoroughly cleared of the drill cuttings that hampered op-

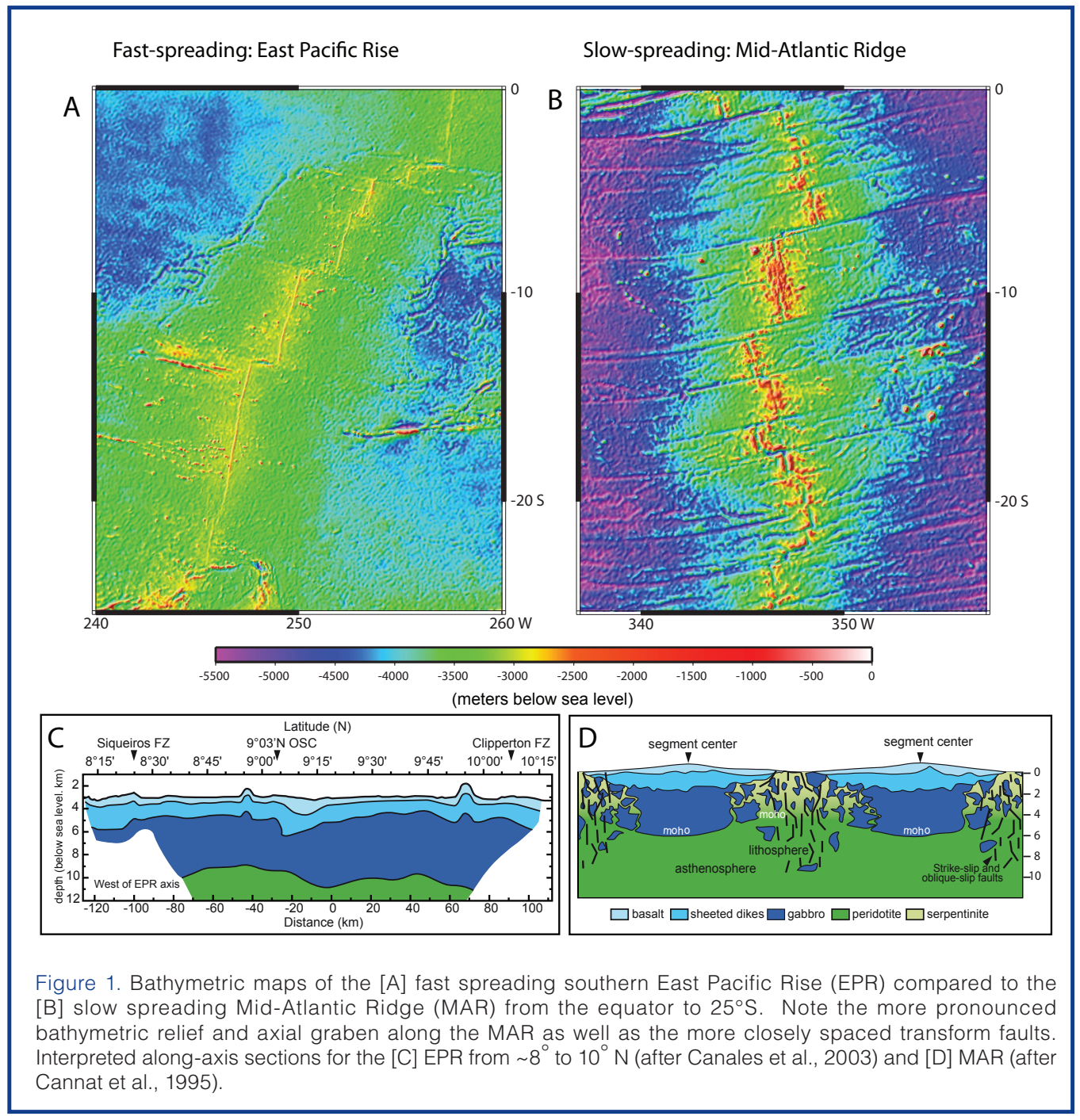


and crystallizes in the lower portion of the ocean crust. Seismic, bathymetric, and marine geological observations indicate that ocean crust formed at fast spreading rates (full rate $>80 \mathrm{~mm} \mathrm{yr}^{-1}$ ) is much less variable than crust formed at slow spreading rates $\left(<40 \mathrm{~mm} \mathrm{yr}^{-1} ;\right.$ Fig. 1$)$ and is closer to the ideal "Penrose" pseudo-stratigraphy developed from ophiolites. Hence, understanding fast-spreading accretion processes at a few sites might reasonably be extrapolated to describe a significant portion of the Earth's surface. Although $<20 \%$ of modern ridges are moving apart at fast spreading rates (Fig. 2), nearly $50 \%$ of present-day ocean crust and $\sim 30 \%$ of the Earth's surface were produced by this pace of spreading. The great majority of crust that subducted back into the mantle over the past $\sim 200$ m.y. formed at fast-spreading ridges (Müller et al., 2008), making characterizing this style of crust most relevant for understanding the recycling of crustal and ocean-derived components back into the mantle.

The rate of spreading of the oceanic lithosphere has profound effects on the style of accretion at mid-ocean ridges due to changing balances between plate motion, magma production, conductive and hydrothermal cooling, detachment tectonics, and serpentinization of the upper mantle (Fig. 1c vs. 1d; Dick, 1989; Cannat et al., 1995, 2004, 2009; Chen and Phipps Morgan, 1996; Dick et al., 2003; Escartin et al., 2008). Although insights on formation of intrusive crust at detachment-dominated, slow-spread lithosphere have been obtained (e.g., Holes 735B, U1309D, and other sites; ODP Legs 118, 153, 176, 209, and IODP Expeditions 304-305; Dick et al., 2000; Ildefonse et al., 2007; Kelemen et al., 2007), the thermal regime and the melt supply and delivery in these settings differ significantly from those of the axial zone in fast-spreading lithosphere. Detailed understanding of the relatively uniform mechanisms operating at fast spreading ridges would provide a vital benchmark against which heterogeneous accretion on slow-spreading ridges could be compared.

\section{Geological Setting of Site 1256 and Science Objectives of IODP Expedition 335}

IODP Expedition 335 (13 April to 3 June 2011) was the fourth scientific drilling cruise of the Superfast campaign, and it returned to ODP Hole $1256 \mathrm{D}\left(6^{\circ} 44.163^{\prime} \mathrm{N}, 91^{\circ} 56.061^{\prime} \mathrm{W}\right)$ to deepen this ocean crust reference penetration a significant distance into cumulate gabbros. ODP Hole 1256D is located on 15-Ma-crust in the eastern equatorial Pacific Ocean in oceanic basement that formed during a sustained episode of superfast ocean ridge spreading (>200 $\mathrm{mm} \mathrm{yr}^{-1}$; Wilson, 1996). Ocean crust formed at a superfast spreading rate was deliberately targeted because there is strong evidence from mid-ocean ridge seismic experiments that gabbros occur at shallower depths in intact ocean crust with higher spreading rates. Therefore, the often difficult-to-drill upper ocean crust should be relatively thin. Expedition 335 follows on from ODP Leg 206 in 2002 and IODP Expeditions

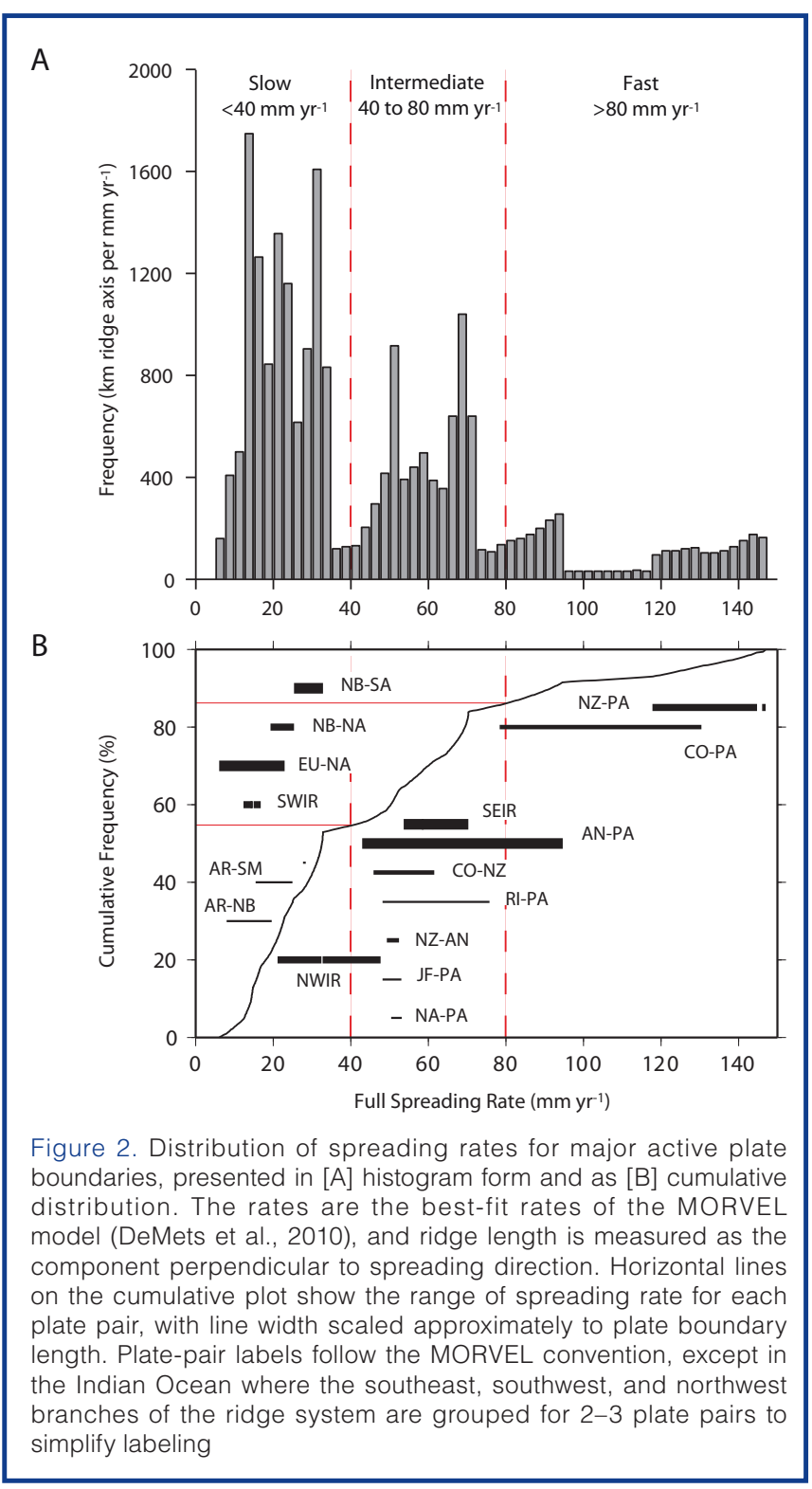

309/312 in 2005 (Wilson et al., 2003; Teagle et al., 2006; Wilson et al., 2006) that prepared the first scientific borehole for deep drilling by installing a large reentry cone secured with almost 270 meters of 16 -inch casing through the 250-m-thick sedimentary overburden and cemented into the uppermost basement. Hole $1256 \mathrm{D}$ was then deepened through a $~ 810$-m-thick sequence of lavas and a thin $(\sim 346 \mathrm{~m})$ sheeted dike complex, the lower 60 meters of which is strongly contact metamorphosed to granoblastic textures (Fig. 4). The first gabbroic rocks were encountered at 1407 meters below seafloor (mbsf) where the hole entered a complex dike-gabbro transition zone that includes two 20- to 50-m thick gabbro lenses intruded into granoblastic dikes. As of the end of Expedition 312 in December 2005, Hole $1256 \mathrm{D}$ had a total depth of $1507.1 \mathrm{mbsf}$, and it was open to its full depth.

It was expected that even with a shortened cruise ( 6 weeks), coring on IODP Expedition 335 would be able to deepen Hole 1256D $\sim 350 \mathrm{~m}$, completely through the dike-gabbro transition zone and varitextured gabbros and a 

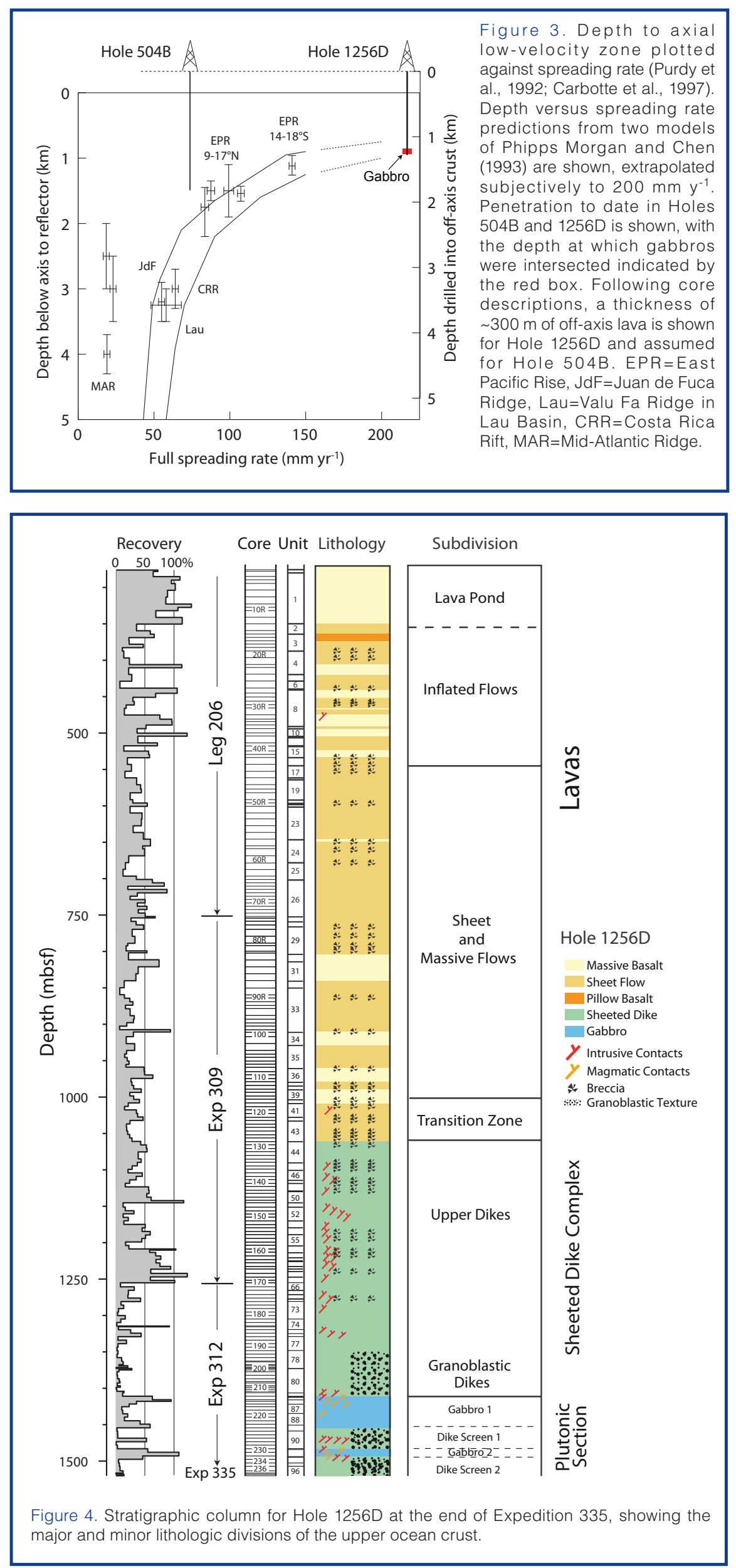

significant distance into true cumulate gabbros. Listed below are the specific scientific objectives of IODP Expedition 335 that were to be addressed by deepening Hole $1256 \mathrm{D}$ a significant distance into cumulate gabbros.

What is the major mechanism of magmatic accretion in crust formed at fast spreading rates? Is the lower crust formed by gabbro glaciers or sheeted sills (Korenaga and Kelemen, 1998; Fig. 5) or by some mixed or unknown mechanism?

How is heat extracted from the lower ocean crust? Specifically, what is the role of hydrothermal circulation in extracting latent heat from the lower ocean crust?

What is the geological significance of the seismic layer $2 / 3$ boundary at Site 1256 ?

What is the magnetic contribution of the gabbro layer? Can the magnetic polarity structure of the lower crust be used to constrain cooling rates?

\section{Operations}

Expedition 335 reentered Hole 1256D more than five years after the last expedition to this site. The expedition encountered and overcame a series of significant engineering challenges, including a major obstruction at a depth of $~ 922$ mbsf that had initially prevented reentry into the hole to its full depth of 1507 meters. At the bottom of the hole, coring resumed in the very hard granular rocks recovered during the previous Superfast expedition. Although there may only be a few tens of meters of these particularly tenacious granoblastic basalts formed by the contact metamorphism of sheeted dikes, their extreme toughness once more proved challenging to sample, resulting in the grinding down of one of the hardest formation coring bits (C9) into a smooth stump (Fig. 6a,b).

Action was then undertaken to clear the bottom of the hole of metal debris from the failed coring bit and drilling cuttings. These efforts returned hundreds of kilograms of rocks and drill cuttings (Fig. 6d), including large blocks (up to $3.5 \mathrm{~kg}$ ) of the 


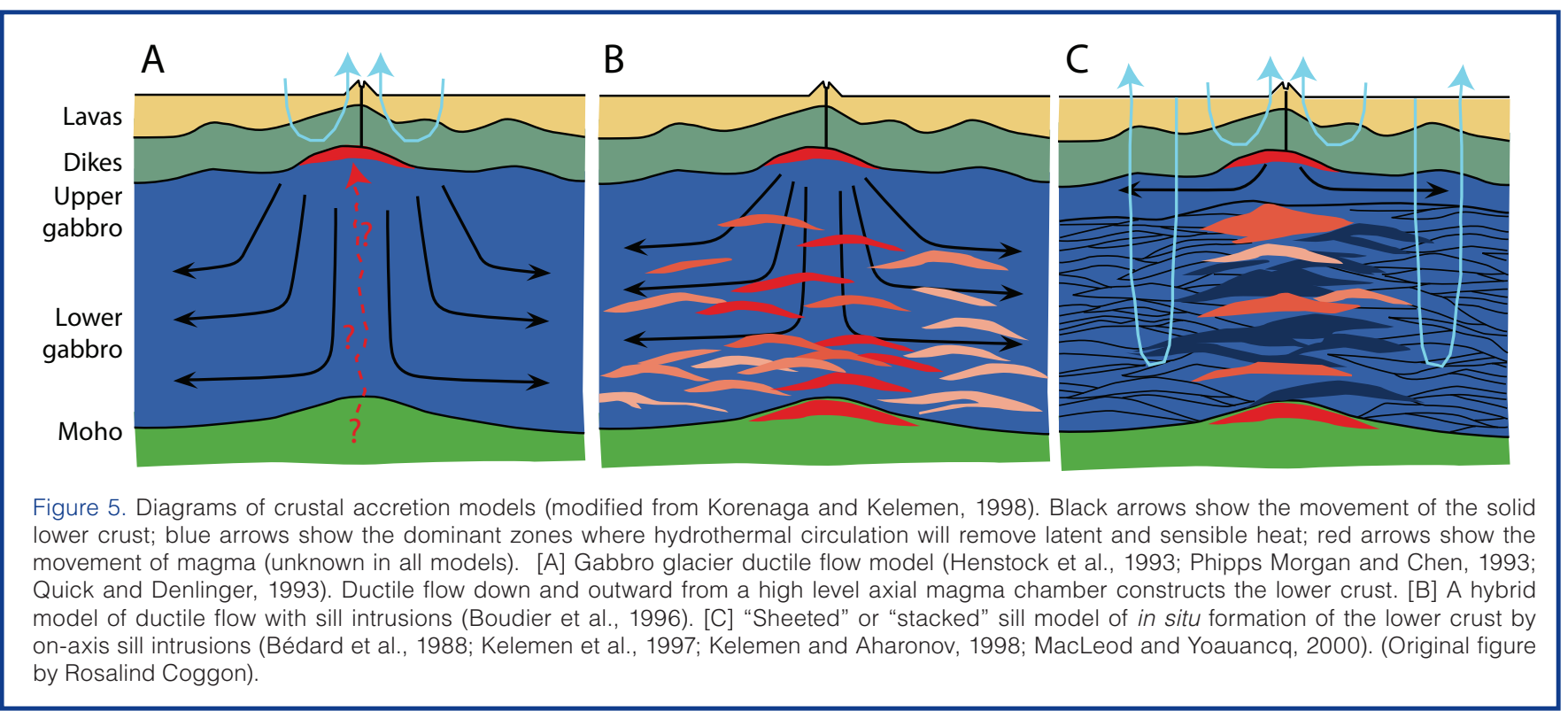

culprit granoblastic basalts that hitherto had only been very poorly recovered through coring . A limited number of gabbro boulders were also recovered, indicating again that we are tantalizingly close to breaking through into the gabbroic layer.

\section{Scientific Results}

Hole opening and remediation operations resulted in a major loss of time from the coring and wireline activities planned for Expedition 335. Coring on this expedition deepened Hole 1256D only modestly, from $1507.1 \mathrm{mbsf}$ to 1521.6 mbsf (Fig. 4) at low rates of penetration $\left(0.9 \mathrm{~m} \mathrm{hr}^{-1}\right)$ and recovery (11\%).

Hole cleaning operations at the bottom of Hole 1256D, particularly thoserunsthat deployed thereverse-circulation junk basket, brought back a unique collection of large cobbles, angular rubble, and fine cuttings of principally strongly to completely recrystallized granoblastic basalt with minor gabbroic rocks and evolved plutonic rocks. The granoblastic basalts record high-temperature (granulite facies) metamorphism of previously hydrothermally altered sheeted dikes, with unequivocal evidence for hydrothermal alteration before and after the formation of granoblastic textures (Teagle et al., 2006; Koepke et al., 2008; France et al., 2009; Alt et al., 2010). The large blocks exhibit intrusive, structural, and textural relationships, and overprinting and cross-cutting hydrothermal alteration and metamorphic paragenetic sequences. Some of the rubble and $\sim 30 \%$ of the fine cuttings recovered by fishing and cleaning operations most likely came from the lava sequences at the top of the hole on the basis of igneous textures and low-temperature alteration minerals (Mg-saponite, amorphous silica). In contrast, the high extent of metamorphic recrystallization exhibited by the granoblastic basalts, and operational factors (e.g., pipe movements), provide strong evidence that the granoblastic
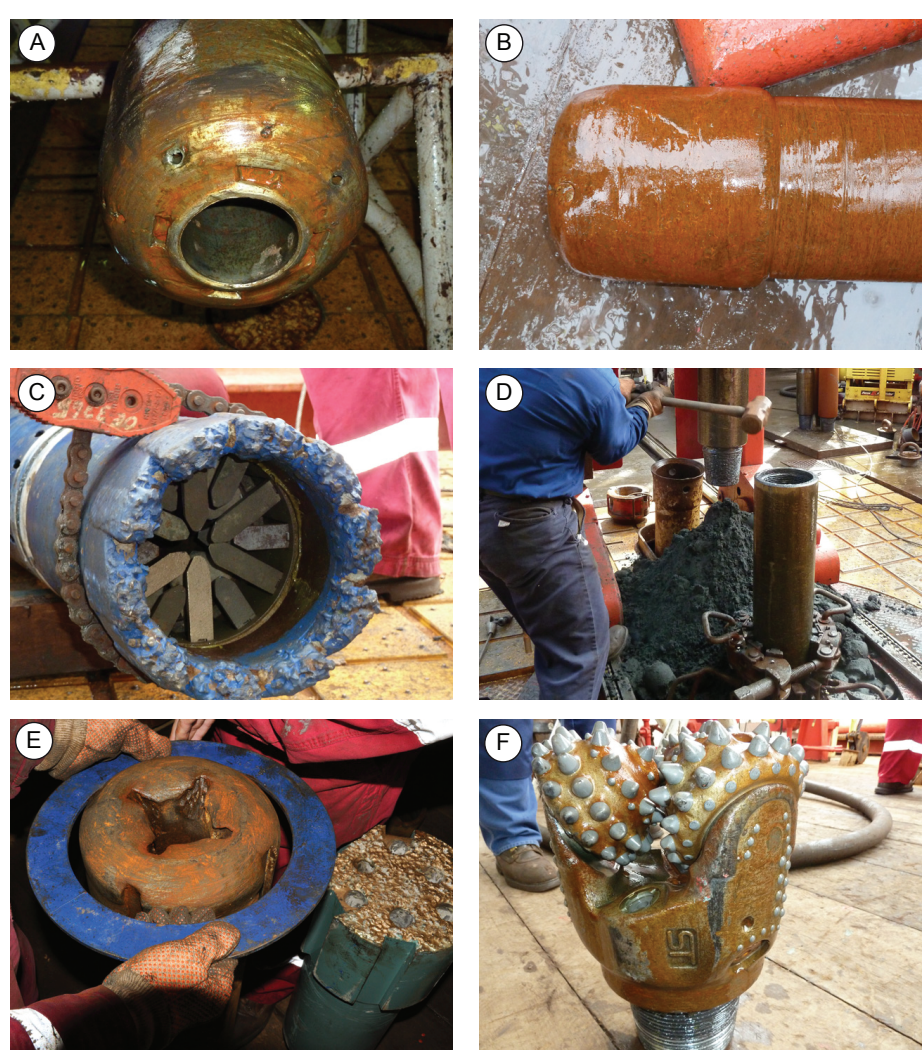

Figure 6. Photographs of some drilling, fishing, and milling tools illustrating the multiple operations achieved during IODP Expedition 335. [A] \& [B] Remains of the Ulterra C9 RCB coring bit used during Run 9. The bit was probably used for $\sim 10 \mathrm{~h}$ after it disintegrated, which resulted in this spectacularly abraded and sculptured bit ("Stumpy"), something never seen before by the drillers. [C] Bottom of the Bowen Reverse Circulation Junk Basket (RCJB), showing its hard-facing structure and the junk catcher spring fingers inside. This tool recovered a series of large-scale cobbles (up to $5 \mathrm{~kg}$ ) of granoblastic basalt. [D] A series of RCJB runs returned a bottom hole assembly packed by fine-grained cuttings. This contributed efficiently to cleaning Hole 1256D. [E] Heavily worn and under-gauge 9-inch flat-bottomed milling tool. This tool worked at the bottom of the hole for $12 \mathrm{~h}$; its final state indicates the very abrasive nature of metal debris and/or rocks at the bottom of the hole and an under-gauge lowermost portion (tens of centimeters) of the hole. Note for comparison the hard-facing structure of the next milling tool on the right side of the picture. [F] 9-inch Smith FH3VPS tricone bit used for Run 16. This armored bit was efficient to ream and clean the under-gauge bottom of the hole. 
basalts, minor gabbros, and evolved plutonic rocks were sourced from the lowermost reaches of Hole 1256D (1494.9-1521.6 mbsf), most probably from below the lower-most recovered gabbroic interval (Fig. 4). Hence, the rocks recovered during Expedition 335 represent a $\sim 15-\mathrm{m}$ interval of the upper crust/lower crust transition, occurring below the $~ 90-\mathrm{m}$ section, recovered during Expedition 312 , of two gabbroic bodies (Gabbro 1 and Gabbro 2) separated by Dike Screen 1 (Fig. 4).

When the textural and contact relationships exhibited by the rocks recovered from the junk baskets are placed in the geological context of the Hole 1256D stratigraphy, a vision emerges of a complex, dynamic thermal boundary layer zone. This region of the crust between the principally hydrothermal domain of the upper crust and the intrusive magmatic domain of the lower crust is one of evolving geological conditions. There is intimate coupling between temporally and spatially intercalated magmatic, hydrothermal, partial melting, intrusive, metamorphic, and retrograde processes.

With only a minor depth advance

in Hole 1256D, we are yet to recover samples of cumulate gabbros required to test models of ocean ridge magmatic accretion and the intensity of hydrothermal cooling at depth. The total vertical thickness of granoblastic basalts is over $114 \mathrm{~m}$, and Dike Screen 2 is now about the same thickness (so far) as Dike Screen 1. Highly perched, isolated gabbro intrusions are uncommon in ophiolites. The energy requirements for the granoblastic recrys-tallization at granulite facies condition of a $>114$-m-thick zone of sheeted dikes massively exceeds the thermal capacity of Gabbros 1 and 2 (Coggon et al., 2008; Koepke et al., 2008) if a simple subhorizontal arrangement of these layers is assumed. The enormous heat requirements for such extensive granulite facies recrystallization, the evidence for partial melting, together with the tantalizing presence of minor but not uncommon gabbroic rocks and felsic intrusives, dikelets, and veins, strongly indicates that the layer of purely plutonic rocks should be at most only a few tens of meters deeper in the hole.

\section{Conclusions}

Although the extensive remedial operations on Expedition 335 precluded significant deepening of Hole 1256D, significant progress was made in improving the stability of the borehole. The most problematic out-of-gauge zone at 920-960 mbsf that caused reentry problems on Expeditions 312 and 335 has been stabilized with cement. The bottom of the hole has been cleared of rubble and junk, and there appears to be only a short $(<1 \mathrm{~m})$ under-gauge zone. What is important is that the regular, large sweeps of high viscosity mud have finally overcome and expunged the vast amount of fine cuttings recirculating in the hole, some most likely resident since ODP Leg 206. This is shown by the absence of soft fill in the final $\sim 5$ reentries, compared to upwards of 50 meters of soft fill at the end of Expedition 312. The engineering efforts on Expedition 335 have repaired and prepared Hole 1256D for further deep drilling, following five years of neglect. Hole 1256D is $1500 \mathrm{~m}$ of hard rock coring closer to cumulate gabbros than any other options in intact ocean crust and once more poised to answer fundamental 
questions about the formation of new crust at fast spreading mid-ocean ridges. This would be best achieved by a timely return to the site.

\section{Acknowledgments}

IODP Expedition 335 was not an easy cruise. Engineering difficulties throughout the expedition presented a continuous series of challenges. The Shipboard Science Party is extremely grateful for the immense efforts of the transocean crew aboard JOIDES Resolution for their perseverance, innovation, open discourse, and "can-do" attitude. This team was aboard when Hole 1256D was first spudded in and cased into basement on ODP Leg 206; they were not going to allow the hole to fail. The Texas A\&M University (TAMU) Operations Superintendent Ron Grout has sailed on three of the four cruises to Hole 1256D, and his advice in testing situations proved invaluable. The proponents of the Superfast campaign thank the IODP Science Advisory Structure (SAS) for their extension of Expedition 335; without the extra two weeks there could have been the catastrophic loss of Hole $1256 \mathrm{D}$, but this extra time allowed the clearing of junk and cuttings and preservation of the hole for future deepening into the cumulate gabbro layers.

\section{IODP Expedition 335 Scientists}

Damon A.H. Teagle (Co-Chief Scientist), Benoit Ildefonse (Co-Chief Scientist), Peter Blum (Staff Scientist), Natsue Abe, Bénédicte Abily, Yoshiko Adashi, Jeffrey C. Alt, Ryo Anma, Graham Baines, Jeremy Deans, Henry J.B. Dick, Daisuke Endo, Eric C. Ferré, Lydéric France, Marguerite Godard, Gilles Guérin, Michelle Harris, Yoon-Mi Kim, Juergen H. Koepke, Mark D. Kurz, C. Johan Lissenberg, Sumio Miyashita, Antony Morris, Ryo Oizumi, Betchaida D. Payot, Marie Python, Parijat Roy, Jessica L. Till, Masako Tominaga, Douglas S. Wilson, and Natalia Zakharova.

\section{References}

Alt, J.C., Laverne, C., Coggon, R.M., Teagle, D.A.H., Banerjee, N.R., Morgan, S., Smith-Duque, C.E., Harris, M., and Galli, L., 2010. Subsurface structure of a submarine hydrothermal system in ocean crust formed at the East Pacific Rise, ODP/ IODP Site 1256. Geochem., Geophys., Geosyst. 11:Q10010Q10038. doi:10.1029/2010GC003144

Bédard, J.H., Sparks, R.S.J., Renner, R., Cheadle, M.J., and Hallworth, M.A., 1988. Peridotite sills and metasomatic gabbros in the Eastern layered series of the Rhum complex. J. Geol. Soc. London, 145(2):207-224. doi:10.1144/gsigs.145.2.0207

Boudier, F., Nicolas, A., and Ildefonse, B., 1996. Magma chambers in the Oman ophiolite: Fed from the top or from the bottom? Earth Planet. Sci. Lett., 144:239-250. doi:10.1016/0012821X(96)00167-7

Canales, J.P., Detrick, R.S., Toomey, D.R., and Wilcock, W.S.D., 2003. Segment-scale variations in the crustal structure of 150-300 kyr old fast spreading oceanic crust (East Pacific Rise, 8 degrees $15^{\prime} \mathrm{N}-10$ degrees $5^{\prime} \mathrm{N}$ ) from wide-angle seismic refraction profiles. Geophys. J. Int., 152:766-794.

Cande, S.C., and Kent, D.V., 1995. Revised calibration of the geomagnetic polarity timescale for the Late Cretaceous and Cenozoic. J. Geophys. Res., 100: 6093-6095. doi:10.1029/ 94JB03098

Cannat, M., Cann, J.R., and Maclennan, J., 2004. Some hard rock constraints on the heat supply to mid-ocean ridges. In German, C., Lin, J., and Parson, L. (Eds.), Mid-Ocean Ridges: Hydrothermal Interactions Between the Lithosphere and Oceans. Geophys. Monogr. Ser., 148:111-150. Washington, D. C. (American Geophysical Union). doi:10.1029/148GM05

Cannat, M., Manatschal, G., Sauter, D., and Peron-Pinvidic, G., 2009. Assessing the conditions of continental breakup at magmapoor rifted margins: What can we learn from slow spreading mid-ocean ridges? Compt. Rend. Geosci. 341:406-427. doi:10.1016/j.crte.2009.01.005

Cannat, M., Mevel, C., Maia, M., Deplus, C., Durand, C., Gente, P., Agrinier, P., et al., 1995. Thin crust, ultramafic exposures, and rugged faulting patterns at Mid-Atlantic Ridge $\left(22^{\circ}-24^{\circ} \mathrm{N}\right)$. Geology, 23:49-52. doi:10.1130/0091-7613 (1995)023\%3C0049:TCUEAR\%3E2.3.CO;2

Carbotte, S., Mutter, C., Mutter, J., and Ponce-Correa, G., 1997. Influence of magma supply and spreading rate on crustal magma bodies and emplacement of the extrusive layer: Insights from the East Pacific Rise at lat $16^{\circ}$ N. Geology, 26: 455-458. doi:10.1130/0091-7613(1998)026<0455:IOMSAS> 2.3.CO;2

Chen, Y.J., and Phipps Morgan, J., 1996. The effects of spreading rate, the magma budget, and the geometry of magma emplacement on the axial heat flux at mid-ocean ridges. J Geophys. Res., 101:11475-11482. doi:10.1029/96JB00330

Coggon, R.M., Alt, J.C., and Teagle, D.A., 2008. Thermal history of ODP Hole 1256D lower sheeted dikes: Petrology, chemistry and geothermometry of the granoblastic dikes. Eos, Trans. Am. Geophys. Union, 89 (53, Suppl.): V44B-08 (Abstract) http://www.agu.org/meetings/fm08/waisfm08.html

DeMets, C., Gordon, R.G., and Argus, D.F., 2010. Geologically current plate motions, Geophys. J. Int., 181:1-80. doi:10.1111/ j.1365-246X.2009.04491.x

Dick, H.J.B., 1989. Abyssal peridotites, very slow spreading ridges and ocean ridge magmatism. In Saunders, A.D., Norry, M.J. (Eds.), Magmatism in the ocean basins. Geol. Soc. Spec. Pub., London, 42:71-105. Oxford (Blackwell Scientific Publications).

Dick, H.J.B., Lin, J., Schouten, H., 2003. An ultraslow-spreading class of ocean ridge. Nature, 426:405-412. doi:10.1038/nature 02128

Dick, H.J.B., Natland, J.H., Alt, J.C., Bach, W., Bideau, D., Gee, J.S., Haggas, S., et al., 2000. A long in situ section of the lower ocean crust: Results of ODP Leg 176 drilling at the Southwest Indian Ridge. Earth Planet. Sci. Lett., 179:31-51. doi:10.1016/S0012-821X(00)00102-3

Escartin, J., Smith, D.K., Cann, J., Schouten, H., Langmuir, C.H., and Escrig, S., 2008. Central role of detachment faults in accretion of slow-spreading oceanic lithosphere. Nature, 455:790-795. doi:10.1038/nature07333 
France, L., Ildefonse, B., and Koepke, J., 2009. Interactions between magma and hydrothermal system in Oman ophiolite and in IODP Hole 1256D: Fossilization of a dynamic melt lens at fast spreading ridges. Geochem. Geophys. Geosys. 10:Q10O19. doi:10.1029/2009GC002652

Henstock, T.J., Woods, A.W., and White, R.S., 1993. The accretion of oceanic crust by episodic sill intrusion. J. Geophys. Res., 98(B3): 4143-4161. doi:10.1029/92JB02661

Ildefonse, B., Blackman, D.K., john, B.E., Ohara, Y., Miller, D.J., MacLeod, C.J., and the IODP Expeditions 304-305 Party, 2007. Oceanic core complexes and crustal accretion at slow-spreading ridges. Geology, 35:623-626. doi:10.1130/ G23531A.1

Kelemen, P.B., and Aharonov, E., 1998. Periodic formation of magma fractures and generations of layered gabbros in the lower crust beneath oceanic spreading ridges. In Buck, W.R., Delaney, P.T., Karson, J.A., and Lagabrielle, Y. (Eds.), Faulting and Magmatism at Mid-Ocean Ridges. Geophysical Monograph, 106:267-289. Washington, DC (American Geophysical Union). doi:10.1029/GM106p0267

Kelemen, P.B., Koga, K. and Shimizu, N., 1997. Geochemistry of gabbro sills in the crust-mantle transition zone of the Oman ophiolite: implications for the origin of the oceanic lower crust. Earth Planet. Sci. Lett., 146:475-488.

Kelemen, P.B., Kikawa, E., Miller, D.J., and Shipboard Scientific Party, 2007. Leg 209 summary: Processes in a $20-\mathrm{km}$-thick conductive boundary layer beneath the Mid-Atlantic Ridge, $14^{\circ}-16^{\circ}$ N. In Kelemen, P.B., Kikawa, E., and Miller, D.J. (Eds.), Proc. ODP, Sci. Results, 209:1-33. College Station, TX (Ocean Drilling Program). doi:10.2973/odp.proc.sr.209. 001.2007

Koepke, J., Christie, D.M., Dziony, W., Holtz, F., Lattard, D., Maclennan, J., Park, S., Scheibner, B., Yamasaki, T., and Yamazaki, S., 2008. Petrography of the dike-gabbro transition at IODP Site 1256 (equatorial Pacific): the evolution of the granoblastic dikes. Geochem., Geophys., Geosyst., 9(7):Q07O09-Q07O37. doi:10.1029/2008GC001939

Korenaga, J., and Kelemen, P.B., 1998. Melt migration through the oceanic lower crust: A constraint from melt percolation modeling with finite solid diffusion. Earth Planet. Sci. Lett., 156:1-11. doi:10.1016/S0012-821X(98)00004-1

MacLeod, C.J., and Yaouancq, G., 2000. A fossil melt lens in the Oman ophiolite: Implications for magma chamber processes at fast spreading ridges. Earth Planet. Sci. Lett., 176:357-373. doi:10.1016/S0012-821X(00)00020-0

Müller, R.D., Sdrolias, M., Gaina, C., and Roest, W.R., 2008. Age, spreading rates, and spreading asymmetry of the world's ocean crust. Geochem. Geophys. Geosys., 9:Q04006. doi:10.1029/2007GC001743

Phipps Morgan, J., and Chen, Y.J., 1993. The genesis of oceanic crust: Magma injection, hydrothermal circulation, and crustal flow. J. Geophys. Res., 98:6283-6297. doi:10.1029/92JB02650

Purdy, G.M., Kong, L.S.L., Christeson, G.L., and Solomon, S.C., 1992. Relationship between spreading rate and the seismic structure of mid-ocean ridges. Nature, 355:815-817. doi:10.1038/355815a0

Quick, J.E., and Denlinger, R.P., 1993. Ductile deformation and the origin of layered gabbro in ophiolites. J. Geophys. Res., 98:14015-14027. doi:10.1029/93JB00698

Teagle, D.A.H., Alt, J.C., Umino, S., Miyashita, S., Banerjee, N.R., Wilson, D.S., and Expedition 309/312 Scientists, 2006. Proc. IODP, 309/312: Washington, DC (Integrated Ocean Drilling Program Management International, Inc.). doi:10.2204/iodp.proc.309312.2006

Wilson, D.S., 1996. Fastest known spreading on the Miocene Cocos-Pacific Plate Boundary. Geophys. Res. Lett., 23:3003-3006. doi:10.1029/96GL02893

Wilson, D.S., Teagle, D.A.H., Acton, G.D., et al., 2003. Proc. ODP, Init. Repts., 206: College Station, TX (Ocean Drilling Program). doi:10.2973/odp.proc.ir.206.2003.

Wilson, D.S., Teagle, D.A.H., Alt, J.C., Banerjee, N.R., Umino, S., Miyashita, S., Acton, G.D., et al., 2006. Drilling to gabbro in intact ocean crust. Science, 312(5776):1016-1020. doi:10.1126/science. 1126090

\section{Authors}

Damon A.H. Teagle, National Oceanography Centre, Southampton, University of Southampton Waterfront Campus, European Way, Southampton SO14 3ZH, U.K., e-mail: Damon.Teagle@southampton.ac.uk.

Benoit Ildefonse, Géosciences Montpellier, CNRS, Université Montpellier 2, CC 60, 34095 montpellier cédex 05, France.

Peter Blum, Integrated Ocean Drilling Program, Texas A\&M University, 1000 Discovery Drive, College Station, TX 77845-9547, U.S.A.

\section{and the IODP Expedition 335 Scientists}

\section{Photo Credit}

Fig. 6: Photos $[\mathrm{A}]$ to $[\mathrm{D}]$, and $[\mathrm{F}]$ : Benoit Ildefonse, CNRS; Photo [E]: Johan Lissenberg, Cardiff University. 